\title{
ITTZÉS MIHÁLY KODÁLY ZOLTÁNRÓL MINT ABSZOLÚT PEDAGÓGUSRÓL
}

\section{MIHÁLY ITTZÉS ON ZOLTÁN KODÁLY AS AN ABSOLUTE PEDAGOGUE}

\author{
Hudra Árpád \\ filozófus, újságíró \\ hudir@t-online.hu
}

\begin{abstract}
ÖSSZEFOGLALÁS
Ittzés Mihály, zenepedagógus és zenetörténész, előadásában Kodály Zoltán életpályáját áttekintve, a belső és a külső tényezőket mérlegre téve vizsgálta meg, hogy Kodály mennyiben tekinthető abszolút pedagógusnak. Egyetértett azzal a megállapítással, hogy az egyébként sokoldalúan tehetséges Kodály zeneszerzőnek született. Ezért, véleménye szerint, nem az önmegvalósítás vágya, hanem a szükség tette pedagógussá, jóllehet ehhez megvolt a belső késztetése is. Úgy látta, Kodály rendszeres zeneakadémiai működésének befejezése után döbbent rá igazán, hogy megfelelő zenetanárok hiányában „nem sok juthat belőlem az iskolába". Ekkor kezdett el a zenei köznevelés ügyével foglalkozni. Ekkor állított össze zenei anyagokat (Iskolai énekgyüjtemény, Szó-Mi iskolai füzetek), amelyek alapján a zenei oktatás módszerét is meg lehetett újítani. Ittzés ugyanakkor rámutatott arra is, hogy Kodály már a Psalmus Hungaricus megírásával a közösségi művészet felé fordult. Az általa feldolgozott gyermekdalok pedig népzenei összművészeti alkotások. Pedagógiai érdeklődése és elkötelezettsége már az 1920-as években feléledt, Praeceptor Hungariae akart lenni. Milyen tanár volt a Zeneakadémián zeneszerzést és zeneelméletet tanító Kodály? Tanítványai szerint karizmatikus egyéniség, aki a mesterségre tanította meg őket egy minden növendék egyéniségéhez simuló tanítóművészettel.
\end{abstract}

\section{ABSTRACT}

In his presentation reviewing the career of Zoltán Kodály while evaluating internal and external factors, Mihály Ittzés, music pedagogue and music historian examined to what extent Kodály can be regarded as an absolute pedagogue. He agreed on the conclusion that Kodály, a man of many talents, was born to be a composer. Therefore, he believes, Kodály became a teacher not so much a for finding personal fulfilment but because of necessity, although he also had an inward urge to do so. He thought that Kodály discovered after completing his regular duties at the Academy of Music that 'no way schools can get a proper amount of me' for lack of appropriate music teachers. That is when he started to engage in music education for the public. He compiled good music materials (Song Collection for Schools, So-Mi workbooks), presenting an opportunity to reform music education methods. At the same time, as Ittzés highlighted, 
Kodály turned to communal art as early as composing Psalmus Hungaricus. The children songs he arranged are comprehensive artworks in folk music. His educational interest and commitment were shown as early as the 1920s, he wanted to be Praeceptor Hungariae. What kind of teacher was Kodály, who taught musical composition and music theory at the Academy of Music? According to his students, a charismatic figure, who taught them crafts with a teaching art suitabe for all kinds of pupils.

Kulcsszavak: zenei köznevelés, karizma, világszerűség, alázat, Gesamtkuntswerk (összművészet)

Keywords: music education, charisma, worldliness, humbleness, Gesamtkunstwerk (comprehensive artwork)

Ittzés Mihály, zenepedagógus és zenetörténész, a Kiss Árpád Műhely felkérésére tartott előadást Kodály Zoltánról az abszolút pedagógusokkal foglalkozó vitasorozat keretében 2016. november 8-án a kecskeméti Neumann János Egyetem Pedagógusképző Karán. ${ }^{1}$ A felkérés Kodály Zoltán életének és munkásságának nemzetközileg is ismert kutatójának szólt, aki ebben a témában 2002-ben védte meg zenetudományi doktori disszertációját a finnországi Jyväskylä-i Egyetemen Zoltán Kodály, in Retrospect címmel. A meghívók számára Ittzés Mihály egész életútja tanúsította Kodály munkásságához való kötődését, hiszen megalakulásától a kecskeméti Kodály Intézet tanára, majd 1980-2001 között igazgatóhelyettese, illetve közben két évig megbízott igazgatója volt. Ezenkívül szervezője a Nemzetközi Kodály Szemináriumoknak, 1993-2001 között a Nemzetközi Kodály Társaság alelnöki, 2007-től a Magyar Kodály Társaság társelnöki, majd 2012-től elnöki tisztségét töltötte be.

Mi az, hogy abszolút? - tette fel a kérdést Ittzés Mihály Kodály Zoltánról szóló előadása elején az abszolút pedagógus fogalma kapcsán. Sokféle abszolút van. Vannak abszolút viccek, abszolút nulla fok, abszolút hallás, abszolút hangok és így tovább. Számára mindebből az látszik biztosnak, hogy az abszolút valamiféle értékmérő. Ezért, amikor felkérték előadása megtartására, s elmondták neki azoknak a nevét, akiket az említettek körébe sorolnak, az az érzése támadt, hogy igazságtalan a mérce. Kimaradtak ugyanis a pedagógiának azok a névtelen hősei, akik nemzedékeket tanítottak írni és olvasni, idegen nyelven beszélni, azonban soha nem váltak országosan ismertté. Véleménye szerint ezért tágítani kellene „lefelé” a kifejezés értelmét. Ugyanakkor hangsúlyozta, hogy „megpróbálja” Ko-

\footnotetext{
${ }^{1}$ Ittzés Mihály (1938-2018) betegsége miatt már nem vállalhatta, hogy előadását tanulmány formájában is megírja. Ezért e cikk szerzője, Hudra Árpád készítette el a videófelvétel alapján az előadás írásos változatát és az azt követő vita összefoglalását.
} 
dály Zoltán (1882-1967) munkásságát az abszolút pedagógusnak a Kiss Árpád Mühely által eddig kidolgozott fogalmi szempontjai szerint bemutatni, azt vezérfonalnak venni.

Aligha vonhatjuk kétségbe, mondta, hogy Kodály többoldalú kiemelkedö tehetség volt. Zeneszerzőnek született, ahogy Eősze László zenetörténész meghatározta, majd tanultsága révén lett zenetudós, pedagógussá pedig a szükség tette. Utóbbihoz nyilván megvolt a belső készsége is.

Ittzés elmondta, Kodály valahol azt írta, diákkorában (1892 és 1900 között a neves nagyszombati érseki gimnáziumban tanult) volt idő, amikor úgy gondolta, hogy festőművész lesz. A már kisgyermekkorában komoly zenei tehetséget mutató Kodályt szülei nem akarták zenésznek adni. A zenélést ugyan szép dolognak tartották, hiszen édesanyja énekelt és zongorázott, édesapja pedig hegedült, és nagyon szerette a klasszikus kamarazenét. Vasúti állomásfönök létére baráti köréből komolyzenét előadó társaságokat verbuvált különböző állomáshelyein. A szülők úgy gondolták, hogy fiúknak nem zenét, hanem „komolyabb” dolgokat kellene tanulnia a gimnázium elvégzése után. Legyen jogász, mert abból minden lehet. Ittzés szerint Kodály azzal, hogy két szakmát tanult egyszerre, olyan életmodellt indított útjára, amely folytatódott a következö zenei generációknál. Hiszen egyfelől zeneszerző lett, mert azt akarta kitanulni. Amatőr felkészültséggel úgy ment a Zeneakadémiára 1900-ban, hogy rögtön a második évfolyamba akarták felvenni, de ő azt mondta, hogy nem, végig akarja járni az iskolát. A Zeneakadémiával párhuzamosan, az Eötvös Collegium tagjaként elvégezte a német-magyar szakot is a budapesti Pázmány Péter Tudományegyetemen. Ez azt jelenti, hogy többlettudást kaphatott, amit ki is használt, olyan kiváló kollégák és barátok társaságában, mint például kollégiumi szobatársa Balázs Béla (Bauer Herbert Béla), a leendő költő, író, filmesztéta vagy Horváth János, a későbbi jeles irodalomtörténész.

Az abszolút pedagógus a tehetségét a pedagógia területére fókuszálja - idézte a következő megállapítást a zenetörténész. Kodály ezt tette? Igenis meg nem is. Valószínúleg nem volt véletlen, hogy amikor 1907-ben Bartók Bélát, meg őt is kinevezték a Zeneakadémiára, Kodály a zeneelmélet tanítását kapta meg, aztán rövidesen zeneszerzést is tanított, Bartók pedig mint gyakorló muzsikus, zongoraszakon lett tanár, amit ő nem nagyon szeretett.

Visszatérve az eredeti kérdésre, Ittzés ismét hangsúlyozta, hogy Kodályt igenis a szükség tette pedagógussá, legalábbis abban az értelemben, ahogyan Kodályt ma mint a nagy magyar pedagógusok egyikét tiszteljük. Mert először zeneelméletet, majd zeneszerzést tanított, de a zeneszerzőből minden lehetett, így zenepedagógus is.

Ittzés idézte Faragó László meghatározását, hogy az abszolút pedagógus: „Olyan géniusz, akinek az emberalakítás vágya jelentette léte középpontját.” Ennek révén lehetne megragadni, hogy Kodály milyen pedagógus volt, vagy miért volt abszolút pedagógus - mondta. Erre Kodály saját maga a tanú. Hátrahagyott 
írásainak második kötetében olvasható Zenét az iskolának címü kis írása, ami előszónak készült az 1943-44-ben megjelent, Iskolai énekgyüjtemény címü kétkötetes munkához. Kodály ekkor már túl volt hatvanadik életévén, és abbahagyta rendszeres tanári müködését a Zeneakadémián. „Végiggondoltam, mit tettem eddig? Hisz nemcsak közvetve, zenészek nevelésével, akikből részben tanítók lettek. Közvetlenül is: a kurzuson - sőt »vezetőtanára« is lettem volna vagy mi az ördög! Kevés. E féléves vagy egyéves tanítványokon át nem sok juthat belőlem az iskolába" - írta Kodály. A Zeneakadémián ugyanis volt egy olyan szaktanfolyam, ahol fél vagy egy év alatt szaktanári képesítést adtak annak, akinek már volt pedagógiai vagy tanári képesítése. Ittzés az idézet utolsó két szavára, „belőlem az iskolába" felhívva a figyelmet, kijelentette: Kodály tehát úgy gondolta, hogy az a szellemi, lelki, zenei tartalom, koncepció, ami benne megvan, az érdemes arra, hogy másokon keresztül a napi gyakorlatba kerüljön, az iskolába. Nem nagyképüség? - kérdezte. Nem, nem hiszem. Az életpálya azt igazolta, hogy nem - válaszolta. Majd így folytatta: Kodály hivatkozik Sztankó bácsira, azaz Sztankó Bélára, 1929-től a Zenemüvészeti Főiskola tanárára, aki hiába eszelt ki különböző tanterveket a népiskolai énektanítás számára, „Nem akart képzőbe senki zenetanárnak menni”, mert az egész pedagógiát, iskolai zenetanítást lenézték. „Itt villant fel előttem: tenni kell és éppen nekünk, úgy nevezett jobb zenészeknek. Más súlya lesz, ha olyan foglalkozik vele, aki operát is tud írni, ha kell. Erkel többet használ, ha 1-2 gyengébb operája helyett az ifjúságnak ír (?).” Két mondattal később pedig így folytatja: „De egyre határozottabb volt a belső parancs: itt kell maradni, a keményebb életre, nehezebb munkára. (De: ez a hivatás).” Ittzés szerint Kodály ezután nem nevesítve, de arra utal, hogy a Psalmus Hungaricus sikere, 1928 után, külföldi ajánlatokat kapott, például Amszterdamba. De ő itthon akart maradni a második világháború és 1956 után is. Tette ezt vérségi kötelék (ezzel arra utalt, hogy Kodály anyja lengyel, apja pedig cseh-morva, illetve felmenöileg flandriai származású volt) nélkül is. Kodály szerint „A tennivaló világos volt: egyfelől az iskolán át emelni az egész ország zenei igényét, másfelöl a főiskolán olyan szakembereket nevelni, akik majd hajlandók hasonló irányban munkálkodni." Kodályt sokan szokták úgy emlegetni, hogy nagyszerüen fel tudta ismerni, ki mire való a hívei, tanítványai köréből - tette hozzá Ittzés. Példaként Ádám Jenő zeneszerzőt, zenepedagógust és népdalgyűjtőt, valamint Szőnyi Erzsébet zeneszerzőt, karnagyot és zenepedagógust említette. Kodály a feladatát most abban látta, hogy a népdal külön zenevilága és a nyugati zene külön világa közötti hidat, amelynek építésén addig munkálkodott, a magyarok számára is átjárhatóvá kell tenni. Sztankóék sikertelenségének oka Kodály szerint az volt, hogy a zeneoktatáshoz nem voltak müvek, és rossz volt a módszer. Ittzés véleménye szerint azért érdemes erről szólni, mert ez az egyik indítéka annak, hogy miért kezdett el Kodály a zenei köznevelés ügyével foglalkozni. Próbáltak már néhány nép- és gyermekdalt becsempészni a zenei tankönyvbe, de még mindig a C-dúr 
létra segítségével. Minden C-dúr-ban volt leírva, és ehhez a módszerhez keresték a tananyagot.

Ittzés szerint Kodály nagy felismerése az volt, hogy ha jó zenei anyagunk van, akkor ahhoz kell az oktatás módszerét megtalálni, és nem a fiktív módszerhez az anyagot. Erről tanúskodik az Iskolai énekgyüjtemény, s ehhez készült Ádám Jenőnek a Módszeres énektanitás címü könyve. Ezért került Kodály neve a Szó-Mi iskolai füzetekre és az említett gyüjteményre, mert az alapvető zenei anyagot, igaz az elsőt Ádám Jenő, a másodikat Kerényi György közremúködésével, ő állította össze. Ittzés folytatta Kodály gondolatmenetét: „Nagy lemondással járt (tudniillik, hogy a zenei köznevelés ügyével foglalkozott - I. M.), a lantot gyakran szegre kellett akasztanom. De ezzel is példát akartam adni. Ha valaki nem jut el odáig, hogy a saját lantja zörgetésénél fontosabb tennivalót ismerjen: nem szolgál, csak a maga kedvtelésére él. Hányan le nem tennék egy percre hitvány dorombjukat, pedig másképp hasznos munkát végeznének. [...] Akadtak, akik sajnálták emiatt meg nem írt müveimet." Ittzés visszaemlékezése szerint Farkas Ferenc zeneszerző mondta neki egyszer, amikor interjút csinált vele kecskeméti szerzői estje alkalmával: sajnálják, hogy Kodály nem írt több nagy müvet, elfoglalta magát a pedagógiával. Kodály egyik írásában a sajnálkozóknak a következőképpen válaszolt: „Engem a daimonion késztet mindenre, nyugodtak lehetnek jóakaróim, hogy amely percben egy mü megírására unszol, engedek neki" - idézte Ittzés. Szólt arról is, hogy Kodály egy kései feljegyzéséből tudjuk, zongoráján halomnyi felkérés feküdt, például a münsteri püspöké, és „meg fognak lepődni” - mondta -, Benny Goodman amerikai klarinétmüvész is munkát akart rendelni tőle. Megjegyezte: a megrendelők mindig azt akarják kérni, amit már ismernek a szerzőtől, ő viszont (mármint Kodály) másképpen viszonyult ehhez, és ha meg akart írni valamit, akkor végül is megírta, jóllehet sok-sok vázlata is fennmaradt. Az említettek fényében meglepő, hogy a mai zenepedagógia éppen Kodály nagy műveit mellőzi, mivel azokat nem tartja zenei koncepciójához tartozónak, és csak a kórusműveit használja az oktatásban - tette hozzá.

A pedagógia médiuma így egy sajátos és különös szempontból müvészetté, talán összművészetté is válik - idézte Ittzés az abszolút pedagógus következő jellemzőjét. Véleménye szerint, ha Kodályra gondolunk, akkor az ő köznevelési koncepciója az alkotó és a reprodukáló művészetet egyaránt figyelembe vette. A fordulópont a Psalmus Hungaricus volt, ahol az ,én”-müvek, a kamarazene és a dalköltészet világából váltott át a kórusmüvek, a népdalfeldolgozások, tehát a közösségi müvészet világába. Alkotótársul hívta a közösséget a népzene feldolgozásán keresztül. Bartókkal együtt úgy tartották, hogy ők csak hozzátettek valamit ahhoz, ami már megvolt, „felöltöztették”, vagy belefoglalták valamilyen keretbe. A népzene tehát müvészetté, sőt összmüvészetté vált. A Kodály által feldolgozott gyermekdalok összmüvészeti alkotások. Hiszen van bennük játék, szerepjátszás, még képzőművészet is, ha másképp nem, hát az öltözékekben. Benne 
van a költészet a szövegben, a zene a dallamokban. Ez valóban egy ösi, variatív jellegü összművészet, amelyet Kodály öntött formába. Villőnek nevezte el, Lengyel Lászlónak, Gergelyjárásnak és így tovább. A Lengyel László nem más, mint „történelmi lecke fiúknak”.

Ittzés utalt arra, hogy sokan azt mondják, Kodály nem írt átfogó módszertant. Valóban nem lehet módszernek nevezni azt, amit csinált - tette hozzá. Ugyanakkor viszont hangsúlyozta: Kodály kidolgozta a zenei köznevelés teljes körü koncepcióját.

Ittzés a vezérfonalat követve folytatta az előadást. Az abszolút pedagógus a maga minősített és bizonyított képességeit a pedagógia médiumában valósítja meg, választása nem a történelmi körülmények okozta kényszerhelyzet, de szabad elhatározás az önmegvalósításra. Ezzel összefüggésben hangsúlyozta: nem ok nélkül idézte korábban Eősze Lászlótól azt, hogy Kodályt a szükség tette tágabb értelemben pedagógussá. Kétségbe vonta, hogy Kodályt a szabad elhatározás az önmegvalósításra vezette a pedagógiába. Nem az volt neki a fontos, hogy a szükebb pedagógiában legyen önmegvalósító, hanem az a már idézett, keményebb élet és nehezebb munka volt a hivatása, amelyre belső parancsa ösztökélte. Nemcsak azok a darabok, amelyeket a gyerekeknek írt, például a 333 olvasógyakorlat vagy a Bicinia Hungarica pedagógiai mü zenei és egyéb értelemben, hanem nagyon sok alkotása társadalmi célú pedagógiai igénnyel és nevelő szándékkal is készült. Amit például más nem mert vagy nem tudott megtenni 1944-ben, azt ő megtette, amikor férfikarra írva megzenésítette Petőfi Sándor Isten csodája címü versét, melynek záró sora: „Emberségünkből álljon fönn hazánk.” Vagy 1944-ben az Éneklö Ifjúság szeptember 15-i számában Mire való a zenei önképzökör címü cikkéhez kánont is írt egy 19. század eleji táncoló alapján: „Magyar, magyart rontja, kár! Bár több esze volna már!” Vagy 1958 januárjában az Énektanitás címü, újra megjelent zenepedagógiai folyóirat bevezetőjében azt írta, hogy „aura libertas!” vagyis „arany szabadság”. Mi ez, ha nem tanítás? - tette fel a kérdést Ittzés.

Véleménye szerint Kodálynál a kettő együtt érvényes, van a belső és van a külső körülmények felismeréséből eredő késztetés. Az 1920-as években Kodályt két, számára meghatározó indíttatást jelentő esemény is érte. Az egyik, a pozitív, a Wesselényi utcai fiúk kórusa volt, akik beszálltak a Psalmus kórusát erősíteni, és olyan élményt jelentettek, hogy elhatározta, nekik írni kell valamit, amit aztán meg is tett. A másik, az ismert, de Kodálynak igen negatív élményt okozó eset az volt, amikor a budai hegyekben a Schneider Fánit hallotta énekelni a Damjanich utcai tanítóképzős lányoktól, amit a zenei züllöttség jelének tartott. Ittzés szerint ez a kettős tapasztalat indította el, ezeken alapult Kodály pedagógiai érdeklődése. A művészi szinttől „ment lejjebb”, amikor 1937-től elindult az Éneklő Ifjúság mozgalom, és 37-ben megjelent a Bicinia Hungarica első kötete. Ekkor esik először szó Kodálynál konkrét pedagógiai módszertani kérdésekről. Egészen 
addig csak a művek és a művészet volt számára a fontos. De rájött, hogy ennek a mủvészetnek a megvalósításához valamilyen zenei technikai alap kell az oktatásban, és ehhez több tudományra és tanítványokra van szüksége. Mit mondott erről a szélesebb körű pedagógiáról? „Praeceptor Hungariae (= Magyarország tanára) akartam lenni (az magyarok nem tanulják az Musikát) [ha jól tudom, ezt valahol Misztótfalusi Kis Miklóstól idézi más helyen - I. M.], de hogy más országé, arra sohasem gondoltam. Aminthogy arra sem, hogy más népeknek komponáljak. Ha mégis úgy jött, nem tehetek róla.” Ittzés szerint „tudjuk”, hogy mi volt az indítéka az 5 fokú zene 3. és 4 . füzetének. A 4. füzetben Kodály meghirdette a világzenét Goethe világirodalmi eszméje nyomán. De amikor a finn dallamokat bevette a Bicinia Hungarica negyedik füzetébe, akkor nemcsak Ilmari Krohnnak meg a finn népzenetudománynak akart tisztelettel áldozni, hanem melléje tette, ahogy Eősze László mondta, a finn-orosz háború idején, 1943-44-ben, a Vejnemöjnent. Amikor a 4. kötetben azt éneklik, hogy a komoly, öreg varázsló, Vejnemöjnen éldegél egy idegen Kalevala hegyén, földjén, ott elénekelvén: „ez ínséges esztendőben, elveszendő nagy időben", nem lehet nem érteni, hogy ez akkor valami többet jelentett az adott korban. Ez ugyanis arra tanított, hogy tessék odafigyelni a finn példára, nemcsak a finn népzenetudományra: kis nép, amelyik meg tudja védeni magát. Lehet, hogy ez belemagyarázás, de amikor arról beszélünk, hogy abszolút pedagógus, akkor egy ilyen kapacitású és volumenủ ember, mint Kodály esetében ezeket az apró dolgokat is érdemes figyelembe venni - hangsúlyozta Ittzés.

Majd idézte a következő meghatározást, azt, hogy az abszolút pedagógus jelentős önálló alkotói tevékenységgel rendelkezzék, a pedagógiai és az értelmiségi alkotás harmóniában álljon egymással. Szerinte ezt nem kell magyarázni Kodálynál, mert ez igen kiemelkedő módon adott volt nála. Mert mi más lenne a sokoldalú tehetség, az értelmiségi hozzáállás, a sok írás, véleménynyilvánítás, nemcsak a zenei nevelés, hanem általában a nevelés ügye érdekében, s nemcsak a zenepolitika, hanem a politika átvitt értelmében is. Ahogy az 1920-as fegyelmi tárgyalás idején mondta védekezésül, amikor a Tanácsköztársaság zenei direktóriumában való részvétele miatt hazaellenességgel vádolták: „A napi politikával nem foglalkoztam. Átvitt értelemben azonban politikai minden taktus, minden népdal, melyet feljegyeztem. Szerintem ez a helyes nemzeti politika. A tetteké és nem a frázisoké."

Az abszolút pedagógus tevékenységének a világszerüség a központi eleme. Ez azt jelenti, hogy mindig egy egész világot közvetít a tanuló számára, mely a tudásoknak és magatartásoknak minden esetben más-más elemekből összetevődő konkrét együttese - tért vissza a vezérfonalhoz Ittzés. Ezt Kodály esetében azzal világította meg, hogy hogyan tanított, illetve hogyan vélekedtek róla a növendékei. Elmondta, ehhez tudni kell, hogy Kodály három szinten foglalkozott a zenei szakemberek képzésével. Leghosszabb ideig, harmincöt évig zeneszerzést taní- 
tott, aztán népzenetudományt és mellette, közben szolfézst. Akik hozzá jártak, azt mondták, hogy nem volt jó tanár a szó hétköznapi értelmében, Szőnyi Erzsébet például sokkal jobb szolfézsórákat tartott. Volt olyan diák, aki úgy érezte, hogy nem eléggé pedagógus módon értelmezte az ő produkcióját, aztán egy életre megsértődött emiatt. Az érintett egyébként kiváló zenetörténész és zenetudós lett később. A másik terület, amikor általánosságban foglalkozott a zenepedagógiai nevelés kérdéseivel, az iskolarendszerrel. Itt is két szinten, mert a zenei szakoktatás alapszintjei is érdekelték, de elsősorban a zenei közoktatás, a közösség- és közönségnevelés. Egyrészt az énekgyüjtemény szerkesztésével, olvasógyakorlatok komponálásával is hozzájárult ehhez a pedagógiai életmühöz. Másrészt nagyon sok módszertani tanácsa volt, ami az óralátogatások, megfigyelések vagy a gyakorló pedagógusokkal való konzultációk alapján alakult ki benne, ha ő nem is volt olyan egyéniség, hogy elemi iskolában tanítson. Nem mindenki alkalmas arra, hogy egyetemen, és nem mindenki alkalmas arra, hogy elemi iskolában oktasson - vonta le a következtetést Ittzés.

Hogyan nyilvánult meg Kodály karizmatikus egyénisége? - tette fel a kérdést ezt követően. Erre válaszolva elmondta, hogy Kodály 1925-ben írta a tizenhárom fiatal zeneszerzőről szóló nevezetes vitacikkét, amikor a vizsgakoncerten bemutatott művek kapcsán a növendékei többségén ugyancsak elverték a port az idős kritikusok. Ö akkor sok alapvető kérdést kifejtett írásában a közvetlen zeneszerző-tanítás pedagógiájáról. Kodály senkit meg nem bélyegzett, sőt arra törekedett, hogy mindenki szabadon kifejthesse egyéniségét, amennyiben van: „Az egyéni öröklött hajlamokból kell kiindulni. Mert még a kisebb tehetségnek is határozott egyénisége van és csak a maga belső áramlatai irányában fejlődhetik. Itt hibáztam talán a legkevesebbet." Ittzés ezután több tanítvány visszaemlékezéseiből is idézett. Boross Lajos, a „prímáskirály” emlékei szerint Kodály a növendékeinek azt mondta, ne arra törekedjenek, hogy megmutassák, hogyan kell „kukutyin” dúrból mollba modulálni, hanem azt nézzék meg, hogyan csinálta Bach, tanulják meg a mesterséget. Bárdos Lajos zeneszerző 1925-ben feljegyezte, Kodály sohasem mondta az órán, hogy „én”, hanem a tárgy érdekelte, a tárgyon keresztül persze az ember is. Keveset beszélt, annál többet megtanított, megtanította őket saját lábukon állni, felkészülni a mesterségből. Seiber Mátyás, az akkor mindössze huszonegy éves fiatalember, Kodály volt növendéke 1926-ban már Kodály, a tanitó címmel írt visszaemlékezést az előző iskolai évekről: „Úgy érzem, hiba volna Kodály tanításmódszerét itt valamiképp is szétszedni vagy analizálni; nem is lehet, és nem is szabad ennek a különös, élő, folyton fejlődő, minden növendék egyéniségéhez simuló tanításmúvészetnek boncolókéssel nekimenni. Inkább csak az lehet a célunk ezekkel a sorokkal, hogy valamiképpen körvonalazzuk és megértessük azokat a sajátosságait e metódusnak, amelyek teljesen egyedülállóvá teszik a mai pedagógiában. Metódus: rossz szó ebben az esetben. Nem is metódusról van itt tulajdonképpen szó: Kodály tanítása bizonyos értelemben már nem is tanítás, 
hanem sokkal magasabb rendủ valami. Annál a különös, szuggesztív kényszerítő erőnél fogva, mely belőle kiárad, kicsiholja a tanítványból a legjavát annak, amire az képes, ezáltal fejlődését hatalmasan elősegíti, és fantáziáját megtermékenyíti. Mi ennek a hatásnak a titka? Egyes-egyedül a hatalmas egyéniség, a nagy tudás, a géniusz kisugárzása." Doráti Antal karmester és zeneszerző azt hangsúlyozta: Kodálytól megtanultuk, hogy mi a mesterség becsülete. Biztos vagyok benne, hogy Doráti tanítványai közül erkölcsi, müvészi felelősség nélkül senki nem írt le egy hangot sem - tette hozzá Ittzés. Majd visszatért a Seibertől való idézet folytatásához: „Bármilyen jó módszerük legyen is ezeknek [a zeneszerzéstanároknak - I. M.], és bármilyen alaposak legyenek is, tanításuk mégiscsak holt és megmerevedett csontváz Kodály élő hús-vér tanítása mellett, mert hiányzik belőlük a zseni éltető ereje.” Ittzés az írás befejező gondolatai közül kiemelte: „E módszernek legfőbb támasza a régi nagy mesterek stílusának megismertetése. Régi stílusokban és formákban való rendszeres gyakorlatok útján rámutat azok szerves voltára és személyes tulajdonságaikra, és megtanítja a növendéket az igazi müalkotás tiszteletére. Mint minden nagy ember, Kodály is egyesíti magában nemzetének nagy fiát és a »világpolgárt«. Nemzeti anélkül, hogy sovinizmusba esnék vagy látóköre határolt volna, és világpolgár anélkül, hogy elveszítené lába alól a talajt."

Az előadást követő vitában Trencsényi László pedagógiai kutató és Kiss Endre filozófiaprofesszor is megköszönte az előadónak, hogy „hüséges volt a házi feladathoz", illetve komolyan vette az abszolút pedagógus már meglévő definícióját, s azt vezérfonalként használta mondanivalója kifejtése során. Ittzés szerintük sok fontos és érdekes dolgot mondott, ami előrevitte az abszolút pedagógus fogalmának értelmezését. Kiss kiemelte, hogy az előadó igyekezett kritikusan eljárni. Ténylegesen fel kívánta tárni, hogy mikor mik voltak Kodály tevékenységének motívumai, mikor mennyire a külső és mennyire a belső késztetések határozták meg. Lényegesnek tartotta, hogy az előadásból kiderült: a karizma és a világszerüség alázatos, negatív formában jelenik meg Kodálynál, holott a karizmáról azt hisszük, hogy az valami csillogó, mint a karizmatikus vezér esetében. Kodály szerinte az alázat karizmatikusa volt bizonyos értelemben. Az abszolút pedagógus szempontjából fontos, hogy ő azáltal kötötte össze az adott szakmának a világát, hogy a karizma nem valami végső, csillogó valami volt nála, hanem „alázatos folytonosság”. Önmagát is állandó „folytonosságba helyezte”, és minden pillanatban újrafogalmazta. Ez azért is érdekes, mert Kodály társadalmilag korántsem volt alázatos, hanem nagyon is erős érdekérvényesítő képességgel rendelkezett. Tehát olyan általános karizmát csinált a pedagógiai munkából, amely nem volt meg benne. Az előadásból kiderült, hogy az évtizedek során hogyan változtak az önmegvalósítás területei és tartalmai Kodálynál. És volt az a pont, amit Farkas Ferenc szavaival idézett fel Ittzés, amikor már azon kellett gondolkodni, hogy melyik győzött az önmegvalósításban, a zenész alkotó vagy a zenész pedagógus. Kiss kiemelte, hogy a Gesamtkuntswerk (összművészet) gondolatával az előadás 
olyan metaforát adott, ami voltaképpen a Kiss Árpád Műhely tagjainak kellett volna, hogy az eszébe jusson. Mert eddig valahogy kerülgették, hogy az abszolút pedagógusnak mikor mit kell tennie. Az X tanítványnak ezt kell mondani, az Y-nak azt, s ehhez valamilyen elözetes tudással kell rendelkezni, hogy ki az X és ki az Y. Tehát a Gesamtkunstwerknek ilyen elemei is vannak, sok más mellett, amelyek egyike, amit az elóadó említett, hogy a zeneszerzésböl is vezethetnek utak a pedagógiába. Végezetül Hudra Árpád is arról beszélt, hogy az abszolút pedagógus tevékenységének mindenféleképpen koncentrálnia kell a tanítvány személyiségére és kreativitására. Ha egy területen sérül a személyiség, a kreativitás, akkor az más területen sem fog igazán megnyilvánulni. Amennyiben viszont ezt a figyelmet megkapta a tanítvány, akkor lehet, hogy ezt más területen is tudja kamatoztatni. Ittzés ehhez példaként tette hozzá Keszi Imre nevét, aki zeneszerzést is tanult Kodálynál, aztán író lett. 